\title{
Histology Biomarkers in Muscle and Ovary of Mangrove Crab, Perisesarma bidens Exposed to Profenofos
}

\author{
A. Maharajan*, V. Ganapiriya, K. Shanmugavel \\ PG \& Research Department of Zoology, Khadir Mohideen College, Adirampattinam, Thanjavur Dist, Tamil Nadu
}

\section{Email address:}

athimaha@yahoo.co.in (A. Maharajan)

${ }^{*}$ Corresponding author

\section{To cite this article:}

A. Maharajan, V. Ganapiriya, K. Shanmugavel. Histology Biomarkers in Muscle and Ovary of Mangrove Crab, Perisesarma bidens Exposed to Profenofos. International Journal of Biomedical Science and Engineering. Vol. 5, No. 1, 2017, pp. 1-8. doi: 10.11648/j.ijbse.20170501.11

Received: January 7, 2017; Accepted: January 24, 2017; Published: February 21, 2017

\begin{abstract}
The purpose of the present study is to afford information on the outcome of profenofos on the crab, Perisesarma bidens, a biologically momentous mangrove crab. The crabs were exposed to profenofos concentrations of $0.038 \mathrm{ppm}$ and $0.076 \mathrm{ppm}$ (sublethal) for 28 days. The muscle tissue showed disintegrated epidermis with vacuolation, gap formation in between the muscle bundles, necrosis, marked thickening and separation of muscle bundle and pronounced intramuscular oedema with minor dystrophic changes. The histopathological changes in the ovary are destruction of epithelial layer with oocytes degeneration and disorganization of nucleus, pycnosis of nutritive cells and oogonial cells, loosely arranged epithelial cells and vacuolization. The histopathological changes induce toxicity at cellular level and hence all possible measures should be taken to prevent the occurrence of profenofos toxicity in the aquatic environment and crustaceans.
\end{abstract}

Keywords: Profenofos, Mangroves, Perisesarma bidens

\section{Introduction}

India is primarily an agro-based country with more than $60-70 \%$ of its population dependents on agriculture. However, $30 \%$ of its agricultural produce is lost owing to pest infestation. In the absence of a better alternative, deployment of pesticides becomes inevitable despite their known hazardous effects. Utilization of pesticides in India is about 3\% of the total world consumption and is increasing at the rate of $2-5 \%$ per annum [1].

Organophosphorus (OP) pesticides are finding increasing use in recent years since they are biodegradable and therefore persist in the environment only for a short time. Because of their low persistence, repeated applications of these pesticides are being practiced for the control of pests in agricultural fields and thereby large quantities find their way into water bodies [2]. Profenofos, a well known organophosphate pesticide has been in agricultural use over the last two decades for controlling pests of paddy, cotton and tobacco. Profenofos has been classified as a moderately hazardous (Toxicity class II) pesticide by the World Health Organization (WHO) and it has a moderate order of acute toxicity following oral and dermal administration. A large numbers of pesticides for the control various agricultural pests; however, their toxicological impact also extends to non target species like fish [3]. Crab is good indicator of aquatic contamination because its biochemical stress responses are quite similar to those found in mammals [4]. The density of the crabs in mangrove ecosystems can go up to a level of $80-90$ crabs per sq.m [5]. Many species of crabs are burrowing in nature and with their burrowing activity they frequently alter the surface characteristics and drive the nutrient cycling [6]. Wide range of studies is available on macro invertebrates as an indicator species of aquatic habitat but amongst them specifically, brachyuran crabs are an effective indicator of different changes in both abiotic and biotic factors.

Reproduction is a physiological process and is an essential biological need of animals for the continuity of the generation which is known to dominate all other physiological processes. This main function of reproduction is to replace population losses due to death and migration [7] Due to the accumulation of the pollutant in aquatic ecosystem the reproductive process gets decelerated and on the other hand long-term exposure to the pollutant causes a 
considerable damage to the tissues of reproductive organ decelerating the reproductive cycle and restricting the development of eggs. Hatching of the eggs and newly hatched young ones are also affected by the exposure to the pollutants and ultimately reduces their long term exposure more pollutants gets accumulated in the tissue of the animal and thus it becomes unfit for human use.

Histopathological, biochemical, and physiological changes in different species of crustaceans after exposure to endosulfan have been widely reported [8]. Histopathological examination has been increasingly recognized as a valuable tool for the assessment of the impact of environmental pollutants on aquatic animals $[9,10,11,12,13,14,15,16 \& 17]$.

Grapsid crabs in the subfamily Sesarminae are key faunal components of many intertidal mangrove ecosystems. Although their feeding and burrowing activities play important roles in the processing of plant material and nutrient cycling, relatively little known about ecological interactions that regulate populations or influence species composition of intertidal crab assemblages. Perisesarma bidens is a small mangrove crab inhabiting the muddy substratum of estuarine and mangrove environments, and enjoys a wide range of distribution in the tropics. Less attention towards the morphology and histology of the body tissues in crab $P$. bidens in relation with physico-chemical parameters has focused and therefore, the major objective of the present paper is to study histopathological alterations in the muscle and ovary of $P$. bidens.

\section{Material and Methods}

\subsection{Test Animal Collection and Maintenance}

Mangrove crab, Perisesarma bidens of carapace size ranging from $2-4 \mathrm{~cm}$ and weight $20-35 \mathrm{~g}$ was collected from the mangrove regions of Muthupettai, Tamil Nadu. They were transported and kept for acclimatization in rectangular tank of 100 li capacity containing well aerated filtered brackish water maintained at ambient temperature $\left(27 \pm 2^{\circ} \mathrm{C}\right)$ for a period of one week. Before stocking the tank was washed with clean water several times. Finally, the tank was washed with $0.1 \% \quad \mathrm{KMnO}_{4}$ for disinfection. Before introducing into the tank, the crabs were screened for any visible pathological symptoms and were treated with $0.1 \%$ of $\mathrm{KMnO}_{4}$.

\subsection{Exploratory Test}

Exploratory tests, otherwise called range finding test, were carried out to assess the approximate effective concentration range of profenofos required for conducting short term tests to assess the effect of profenofos on the metabolic function ofthe crab, as recommended by APHA [18]. The test solutions were prepared over a wide range of concentrations. These tests were performed by exposing 10 specimens of crab, $P$. bidens in 10 litre fresh water containing different concentrations of profenofos. The dead animals were removed immediately. Death of each animal was recorded.
Three replicates were made for short-term toxicity tests, the least concentration was chosen where no mortality was recorded in $24 \mathrm{hrs}$ and the highest lethal concentration was where $100 \%$ mortality was recorded in $24 \mathrm{hrs}$.

\subsection{Acute Toxicity Test}

To study the toxicity of nitrite, the Static Bioassay Method [18] was followed. The test individuals were exposed to selected and serially diluted profenofos concentrations. For acute toxicity test, 10 active animals each were exposed to various concentrations of profenofos $(0.010,0.020,0.030$, $0.040,0.050,0.060$ and $0.070 \mathrm{ppm})$ using brackish water as control. The manifestation time and survival time of crab were observed. Crabs were exposed to the above said concentrations along with common control. Experimental animals were starved for one week. The experiments were conducted in three replicates at room temperature. No feed was given during the test period.

\subsection{Sub Lethal Toxicity Tests}

For sublethal toxicity tests, the crabs were grouped into three batches. Each batch had 10 animals and had 3 replicates. In the first group the crabs were maintained in normal water and served as control. In the second group the crabs were exposed to the sublethal concentration of $0.0038 \mathrm{ppm}\left(1 / 10^{\text {th }}\right.$ of $\mathrm{LC}_{50}$ value for 96 hours $)$ of profenofos in brackish water. In the third group the crabs were exposed to the sublethal concentration of $0.0076 \mathrm{ppm}$ $\left(1 / 20^{\text {th }}\right.$ of $\mathrm{LC}_{50}$ value for 96 hours) of profenofos in brackish water. The media were renewed every alternate day. Crabs were fed daily with artificial feed. Two specimens each from the groups I, II and III were sacrificed after $0,7^{\text {th }}$ and $28^{\text {th }}$ days of the experiment.

\subsection{Evaluation of Histopathology}

At the interval of $0,7^{\text {th }}$ and $28^{\text {th }}$ days one crab from each concentration of profenofos was picked out randomly. The animal was sacrificed and muscle and ovary tissue in small pieces of $4-5 \mathrm{~mm}$ sizes were fixed immediately in Davidson's Fixative for $24 \mathrm{~h}$. The preserved tissues were processed by a routine histological method [19], dehydrated in alcohol series and embedded in paraffin wax. They were cut into sections of $6 \mathrm{~mm}$ thickness by a rotary microtome (Weswox, MT1090:1090A, India). The thin sections of the tissues were stained by haematoxylin and eosin for observation by the Nikon Bright field transmission microscope with Koechler illumination, and an automatic exposure unit was used.

\section{Results}

\subsection{Acute Toxicity Test}

Acute toxicity study was done to find out the impact of insecticide Profenofos on P. bidens for 96hrs. Among the test concentrations prepared from the preliminary toxicity test the 
mortality of $50 \%$ of the population after $96 \mathrm{hrs}$ exposure was observed on $0.38 \mathrm{ppm}$

\subsection{Histology of Muscle}

The muscle tissue of the control crab was made up of muscle cells containing contractile filaments that move each other and change the size of the cell. Muscle tissue derived from mesoderm contains protein, and myosin filament (thread-like) form multi nucleate cells that assemble into fibers called myofibrils (Plate 1A). The striated muscle fibres were tightly packed. Muscle is the tissue of motion and is widely distributed in various organs of the body. The photomicrograph of the muscle (Figure 1. A and B.) depicted the presence of normal myotomes (MT) with equally spaced muscle bundles the fascicular arrangement of myofilaments (MF) with emarginated epimysium, binding to connective tissue and tendon at the extremities of the smooth muscles. The striated muscle fibres (SM) were tightly packed. The nuclei were arranged alongthe margins of the muscle bundles (Figure 1B).
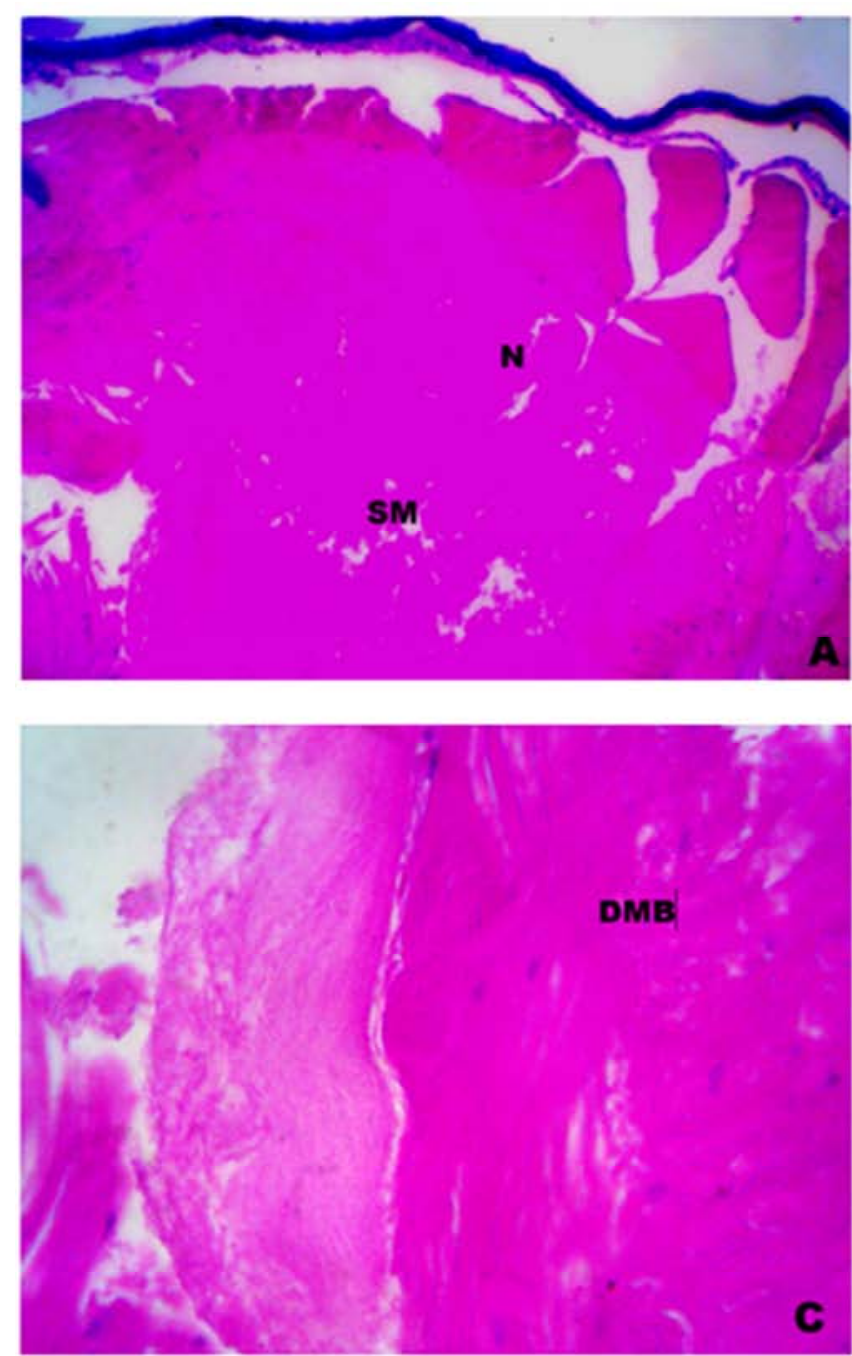

\subsection{Histopathology of Muscle}

After 7 days of exposure, themuscle tissue showed disintegrated epidermis (DE) with vacuolation, gap formation (GF) in between the muscle bundles, necrosis (NE), marked thickening and separation of muscle bundle and pronounced intramuscular oedema with minor dystrophic changes (Figure 1C) In the higher concentration, the muscle bundles are completely disrupted with discontinuity of striations and complete disappearance of nuclei. In some regions of muscle tissue shows the sloughing of epidermal layer (SEL) (Figure 1D) Lesions (LN) and mild haemocyte infiltrations (HI) are the marked changes after 28 days low concentration followed by fusion of muscle bundles (FMB) (Figure 1E). In higher concentration the muscle tissue expressed significant changes like broken myofibrils (BMF), coagulative necrosis (CNE) congestion of muscle bundles followed by rupture of muscle bundles. Severe haemocyte infiltration (HI) and accumulation of granular materials in between the muscle fibers (GMF) are also noted (Figure 1F). Congregation of nucleus occurs in the vacuolated region and banding patterns were completely altered in higher concentration after 28 days of exposure.
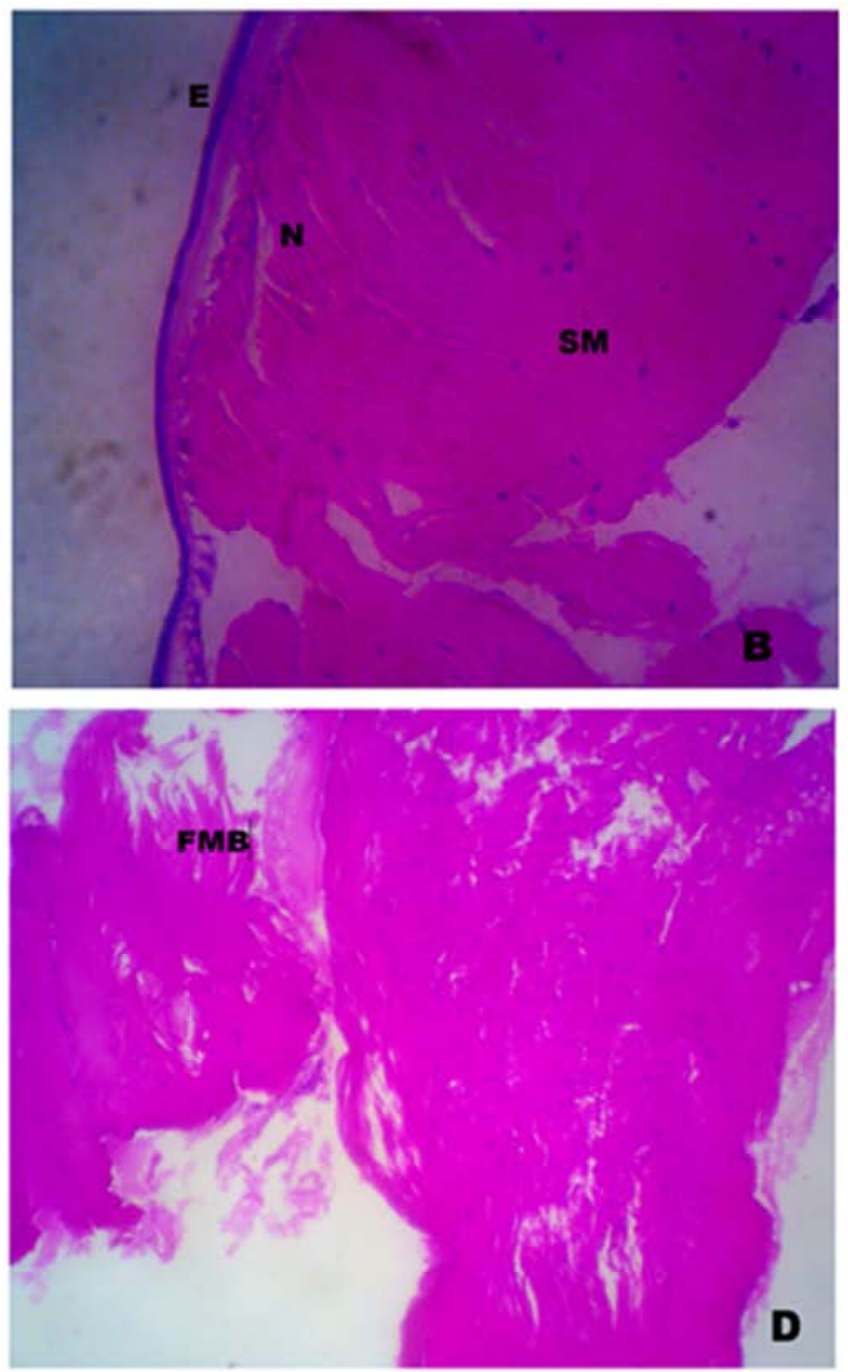

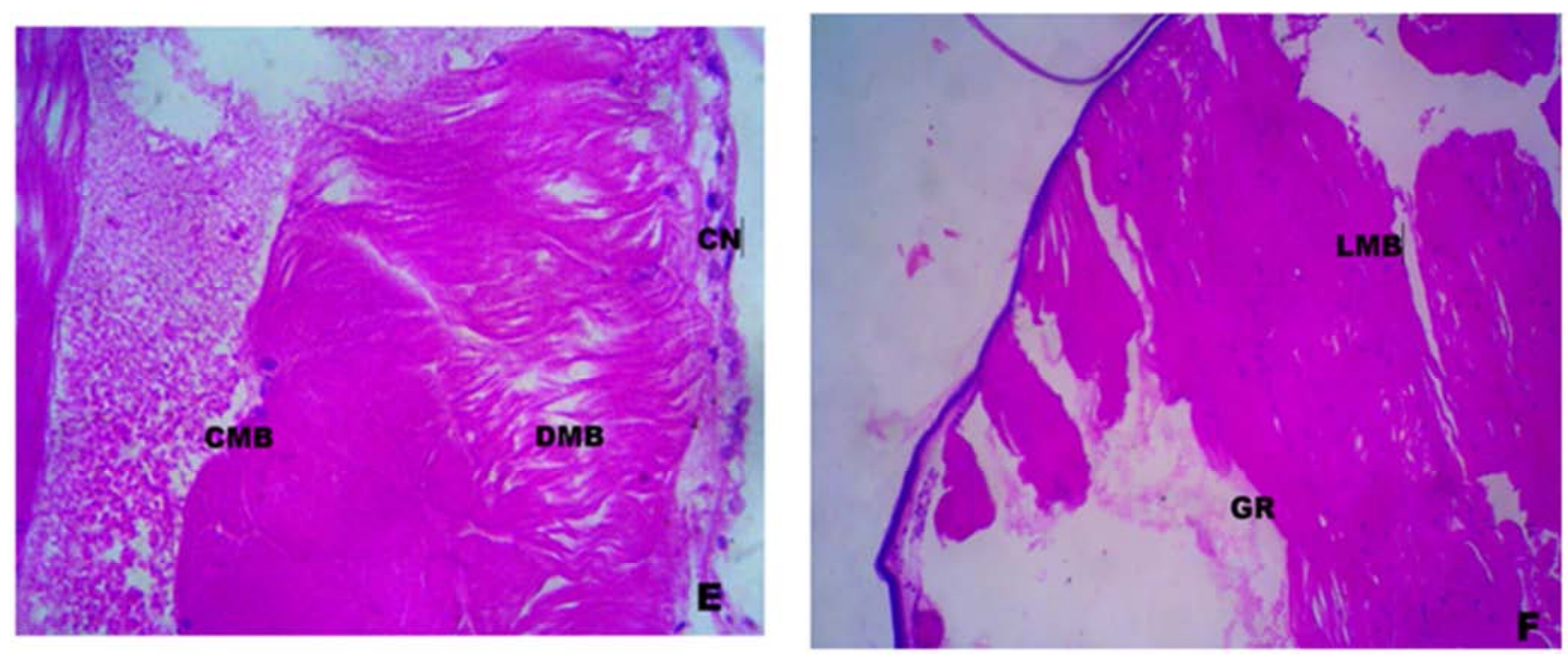

Figure 1. Histological changes of Muscle in P. bidens.

Light microscope of a paraffin section stained with Heamatoxylin and Eosin (40X)

A \& B Control

C-After 7 days of exposure to $0.038 \mathrm{ppm}$ concentration of Profenofos

D-After 28 days of exposure to $0.076 \mathrm{ppm}$ concentration of Profenofos

E-After 7 days of exposure to $0.038 \mathrm{ppm}$ concentration of Profenofos

F-After 28 days of exposure to $0.076 \mathrm{ppm}$ concentration of Profenofos

\subsection{Histology of Ovary}

The ovary of Perisesarma bidens is covered with an outer epithelial membrane followed by connective tissue and inner germinative epithelium. In the early stage of development the germinative zone (GZ) or zone of proliferation is distinguished by the presence of compact mass of oogonial cells which undergo meiotic division and give rise to primary oocytes (previtellogenic oocytes). Each vitellogenic oocyte is covered with a thin layer of follicle cells (Figure 2A). The mature oocytes or vitellogenic oocytes are completely filed with yolk globules and granules. The nutritive cells are present in close vicinity of the oocytes and supply the nutritive material to the developing oocytes. The degenerating ova are surrounded by nutritive phagocytes, which increase in their size with the increase in vacuolization. In fully matured ovary all the above stages of oocytes as well as follicular cells and phagocytes are observed (Figure 2B).

\subsection{Histopathology of Ovary}

Histological observation of ovary exposure to lower concentrations of preofenofos after 7 days showed destruction of epithelial layer with oocytes degeneration and disorganization of nucleus was observed. Pycnosis of nutritive cells and oogonial cells was observed. The epithelial cells become loosely arranged and vacuolization was observed in the periphery of oocytes. After 28 days exposure, the ovary showed irregular shape of oocytes, rupturing of oocytes, mixing of ooplasmic material due to disintegration of follicular epithelium, maximum nature of degenerating oocytes with disintegrated nuclei was observed (Figure $2 \mathrm{C}$ ).

Ovarian cells were destructed; outer thin spermathecal epithelium and inner germinative epithelial layer were damaged. The oocyte covering thin membrane was also enlarged and damaged, with destructed follicle cells. Vacuolation and fragmentation in the follicular cells were observed. Follicular membrane was damaged. Vacuolation in the follicular cells was prominent with less number of matured follicle cells (Figure 2D).

The crabs exposed to profenofos, showed that the thin capsule of fibrous connective tissue enclosing the ovary was destructed, the outer thin epithelium and inner germinative epithelial layer were damaged. The oocyte covering thin membrane was also damaged, and the follicle cells were destructed. Vacuolation and fragmentation in the ooplasm were observed psychosis of nutritive cells and nucleus of oocytes. Thin capsule of fibrous connective tissue enclosing the ovary destructed, Follicular membrane was damaged and vacuolation in the ooplasm was prominent. (Figure $2 \mathrm{E} \& \mathrm{~F}$ ). 

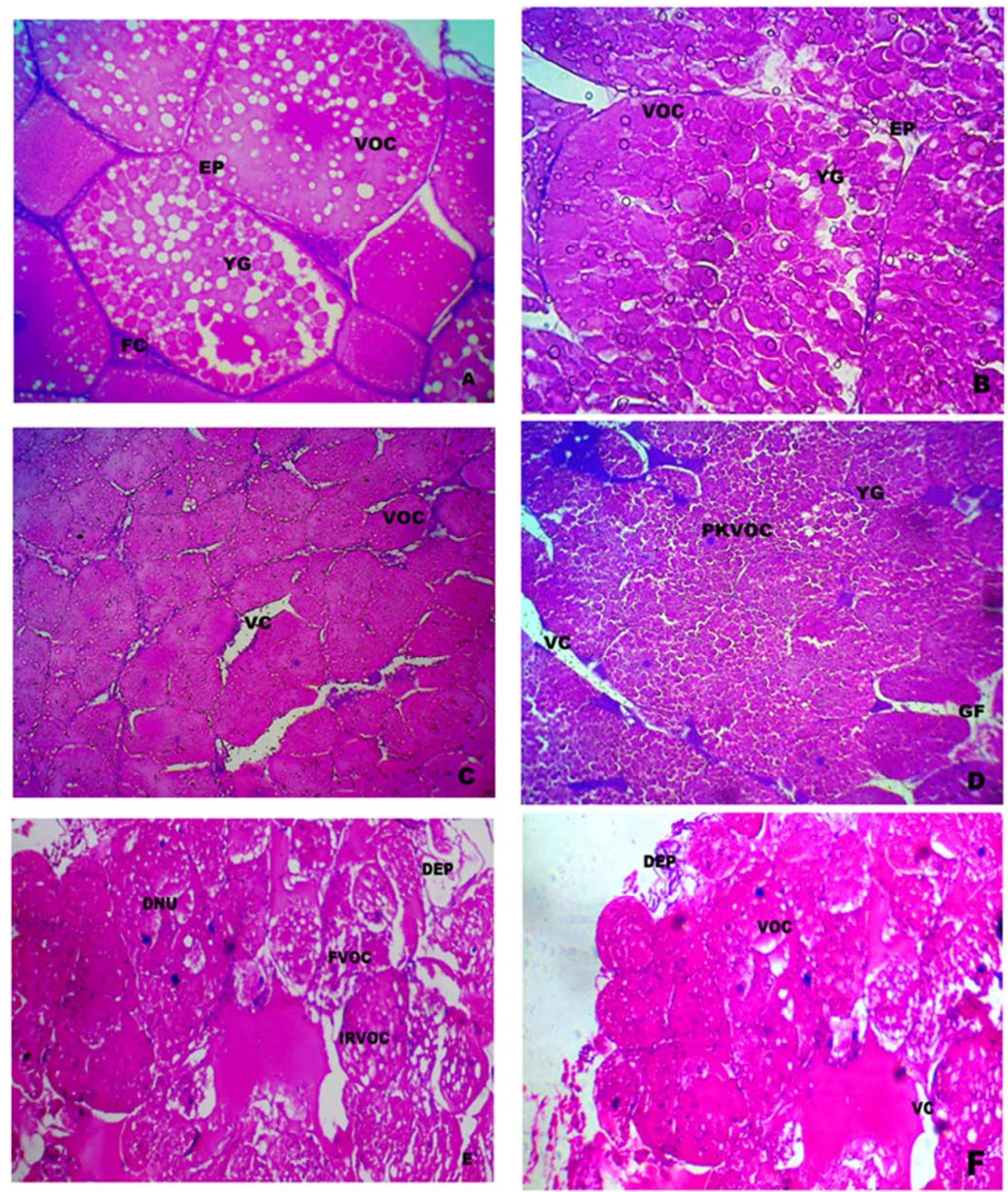

Figure 2. Histological changes of Ovary in P. bidens.

Light microscope of a paraffin section stained with Heamatoxylin and Eosin (40X)

A \& B Control

C-After 7 days of exposure to 0.038 ppm concentration of Profenofos

D-After 28 days of exposure to $0.076 \mathrm{ppm}$ concentration of Profenofos

E-After 7 days of exposure to $0.038 \mathrm{ppm}$ concentration of Profenofos

F-After 28 days of exposure to $0.076 \mathrm{ppm}$ concentration of Profenofos 


\section{Discussion}

In the present study, several histopathological alterations were noticed in the muscles of $P$. bidens when exposed to sub lethal concentration of profenofos. The pathological findings include degeneration of muscles, necroses of muscle fibers with haemorrhages and RBC like pigmented cells. The structural changes noticed in the muscle tissue as atrophy, necrosis, wavy appearance and granular material in between in the muscle fibers, fragmentation, loss of muscle structure, appearance of basophilic deposits of the muscle fibers were caused as a result of exposure of crabs to the sub lethal concentrations

As muscle tissue is the primary site of exposure, pollutants affected the muscle epidermis abruptly. Pigmented cells are prominent feature of chronic inflammatory response. The present investigation closely agreed with a similar report by Tehrani et al.[20] in the muscle tissues of Artemia urmaiana in response to carbamates pesticide resulting in degeneration, Zenkers necrosis of muscle fiber with haemorrhages and RBC like cells. Exposure of Labeo rohita to hexachlorocyclohexane was found to induce separation of muscle bundles and intracellular oedema in the muscle tissues [21]. Moreover, Fatma [22] observed degeneration of muscle bundles with aggregations of inflammatory cells and focal areas of necrosis in the muscle tissues of Tilapia zillii and Solea vulgaris exposed to heavy metal. Such observations were also made in muscle tissues of Oreochromis mossambicus on exposure to dimethoate [23]. Histopathological alterations in the muscle tissues of Heteropneustes fossilis exposed to polluted river water were also recorded by Rakhi et al. [24].

Histopathological alterations in the muscle tissues of Heteropneustes fossilis exposed to polluted river water were also recorded by Rakhi et al. [24]. The present study identified the rupturing of oocytes membrane in the oocytes, Vacuolization in the peripheral oocytes and disturbances in the supporting connective tissue after acute and chronic exposure of profenofos in crab P. bidens. Chourpagar and Kulkarni, [25] observed histological changes in the tissues of freshwater female crab, Barytelphusa cunicularis when exposed to heavy metal pesticides. The reproductive cycle of crustaceans has been widely studied, mainly of those species that have commercial value or ecological potential reported by Castiglioni and Negreiros Franzoso, [26]. Histological studies have a way for understanding the pathological conditions of the animal by helping in diagnosing the abnormalities or damages of the tissues exposed to toxic stress of heavy metals [27]. Histological changes provide an early indication of pollution hazard, and also useful data on nature and degree of damage to cells and tissues [28].

Sarojiniet et al. [29] observed the degeneration of oocytes, vacuolization and replacement of oogonia with fibrous tissue in the ovary of freshwater crab, B. guerini after exposure to zinc sulphate. Kharat et al. [30] observed the gametogenic changes in ovary of freshwater prawn, Macrobrachium kistensis exposed to TBTCL. Tehrani et al. [31] postulated that the degree of damage in the ovaries of Artemia urumiana affected by carbamates pesticide was indicated by necrosis in ovarian nurse cells. Kharat et al. [30] recorded the effects of tributyltin chloride induced histopathological insult of ovarian tissue of freshwater prawn, Macrobrachium kistnensis. They reported marked damages in epithelial layer, degeneration of oocytes, vacuolization appearance in cytoplasm and nucleoplasm. Similarly, Jadhav and Sheikh [32] observed exposure and concentrated mediated changes in ovaries of freshwater crab, Barytelphusa cunicularis treated with endosulfan. Likewise, reported degenerative changes in ovaries of mud crab, Scylla olivacea when exposed to cadmium nanoparticle. Damage to the ovarian tissue may be due to the direct effects of organophosphorus pesticides on developing oocytes interfere with the enzyme system in metabolism or destroying the function of hormone that controlling the ovarian growth and leads to decline reproductive activity.

Ovaries in Macrobrachium kistnensis exhibited epithelial layer destruction, degeneration of oocytes, increased phagocytic cells, vacuolization appearance in cytoplasm and nucleoplasm. TBTCl induced significant alteration in the ovary of the prawn, Macrobrachium kistnensis. As increased in exposure leads to increase in damage to the ovary. This damage observed in the ovary might be due to the direct effects of TBTCl on developing oocytes intervening the enzyme system in metabolism or 50 destroying structure the function of hormone that controlling the ovarian growth [33].

\section{Conclusions and Recommendations}

\subsection{Conclusions}

The histopathological changes in ovarian cells due to contaminated water showed progressive damage and degeneration. This was evident with the exposure of animal to water pollutants extent of tissue damage increases with the increase in water pollution. Damage to ovary due to exposure of hard water pollutants decline in reproductive activity and indirectly reduces the regenerative capacity in the population indices.

\subsection{Recommendations}

Usage of large number of pesticides in agricultural field not only affects the target pests but also the non-target species like fish and crustaceans which inhabit the estuarine and fresh water ecological niche. Due to the accumulation of the pollutant in aquatic ecosystem the reproductive process gets decelerated along with other physiological activities in crustaceans. There should be adoption of remedial measures to prevent profenofos toxicity in aquatic environment. 


\section{Acknowledgements}

Authors would like to acknowledge their gratitude to Science and Engineering Research Board, Department of Science and Technology, New Delhi, India (SB/YS/LS/254/2013) for the financial assistance and Head of the Institution Khadir Mohideen College, Adirampattinam for the facilities provided.

\section{Abbreviations}

SM: -Striated muscle

N: -Nuclei

DMB: Disruption of muscle bundle

E: Epithelium

FMB: Fusion of muscle bundle

GF: Gap formation

$\mathrm{CN}$ : Congestion of nuclei

CMB: Congestion of muscle bundle

LMB: Loosen of muscle bundle

YG: Yolk globules

FC: Follicle cell

EP: Epithelium

VOC: Vitellogenic oocytes

VC: Vacuolation

DEP: Disintegration of epithelium

FVOC: Fragmentation of vitellogenic oocytes

DNU: Disintegrated nucleus

IRVOC: Irregular vitellogenic oocyte

PKVOC: Pknoticvitellogenic oocytes

GF: Gap formation

\section{References}

[1] B. J. Bhadhade, S. S. Sarnaik and P. P. Kanekar, "Bioremediation of an industrial effluent containing monocrotophos". Cur. Microbiol. 2002, 45, 346-349.

[2] B. Jyothi and G. Narayan, "Certain pesticide- induced carbohydrate metabolic disorders in the serum of freshwater fish Clarias batrachus (Linn.)". Food. Chem. Toxicol. 1999, 37, 417-421.

[3] S. M. Naqvi and C. Vaishnavi, "Bioaccumulative potential and toxicity of Endosulfan insecticide to non-target animals". Comp. Biochem. Phys. 1993,105, 347-361.

[4] R. Mishra and S. P. Shukla, "Endosulfan effects on muscle malate dehydrogenase of the fresh water catfish Clarias batrachus". Ecotox. Environ. Safe. 2003, 425-433.

[5] D. J. H. Phillips, and P. S. Rainbow, "Biomonitoring of trace Aquatic contaminants". Chapman and Hall, London. 1994.

[6] P. J. Pandya, "Benthic community structure of Mahi River estuary with special reference to animal-sediment relationship". Ph. D. Thesis, the Maharaja Sayaji rao University of Baroda, Vadodara, Gujarat, India. 2011, p. 23104.

[7] C. E. Warren, "Biology and water pollution control." W.B. Saunders Co. Philadelphia.1971.
[8] S. Selvakumar, S. Ajmal Khan and A. K. Kumaraguru, "Acute toxicity of some heavy metals, pesticides and water soluble fractions of diesel oil to the larvae of some brachyuran crabs". J. Environ. Biol. 1996, 17, 221-226.

[9] P. Peebua, M. Kruatrachue Pokethitiyook and S. Singhakaew, "Histopathological alterations of Nile tilapia Oreochromis niloticus in acute and sub chronic Alachlor exposure". J. Envi. Bio. 2008, 29(3), pp. 325-331.

[10] P. Saravana Bhavan and P. Geraldine, "Manifestation of Carbaryl toxicity on soluble protein and histopathology in the heptopancreas and gills of the prawn, Macrobrachium malcolmsonii”. J. Envi. Bio. 2009, 30(4), pp. 533-538.

[11] M. Manosathiyadevan, V. Selvisabhanayakam and Divya, "Morphological alterations and biochemical contents of the testis of adult male freshwater prawn Macrobrachium malcolmsonii". Ind. J. Fun. App. Lif. Sci. 2012, 2(4), pp.104113.

[12] S. M. Maryam, V. Khalili, A. Abbasiand Hedayati, "Sublethal effect of copper toxicity on liver lesions of Roach (Rutilusrutilus caspicus) juveniles". JNASCI. 2013, 2(4), 119123.

[13] A. R. Chourpagar and G. K. Kulkarani, "Effect of mercuric chloride on gill structure of a freshwater female crab, Barytelphusa cunicularis (Westwood)". J. Glob. Biosci. 2014, $3(2), 423-427$.

[14] A. Maharajan, R. Saraswathi and P. Kumarasamy, "Profenofos induced protein alterations in fresh water crab, Paratelphusa jacquemontii (Rathbun)". Int. J. Pharmaceu. and Biolo. Rese. 2012, Vol. 3, Issue, 3, pp. 127-131.

[15] A. Maharajan. K. Neelakandamoorthy and P. Kumarasamy, "Impact of Profenofos on Oxygen Consumption and Gill Histopathology of the Fresh Water Crab, Paratelphusa jacquemontii (Rathbun)". A J. Toxicol.2012, Vol. 2, Iss. 2, pp. 46-55.

[16] A. Maharajan. V. Ganapiriya. and K. Shanmugavel, "Brachyuran crab diversity in Muthupettai mangroves on southeast coast of Tamil Nadu". Int. J. Fisheri. and Aqua. Stud.2015, 2(5), 30-31.

[17] A. Maharajan, Y. Narayanasamy, V. Ganapiriya and K. Shanmugavel, "Histological alterations of a combination of Chlorpyrifos and Cypermethrin (Nurocombi) 2 Insecticide in the fresh water crab, Paratelphusa jacquemontii (Rathbun)". J. Basic and Appl. Zool. 2015, 72, 104-112.

[18] APHA, "Standard methods for the examination of water and waste water APHA, AWWA and WPCF, New York". 1985.

[19] G. L. Humason, "Animal tissue Techniques," $3^{\text {rd }}$ Ed., W.H. Freeman and Company, San Francisco. 1972.

[20] A. A. G. Tehrani, Z. Sadeghi, N. H. Badamchi Sanjou and A. Mansoub Azhari, "Effect of Carbamates pesticides on Instar III larvae and Adult Artemia urumiana". Annals of Biologi. Resea. 2011, 2(3), 515-525.

[21] S. C. Das BK and A. Mukherjee, "Histopathological study of carp Labeo rohita exposed to Hexachlorocyclohexane". Veterinarski Arhiv. 2000, 70(4), 169-180.

[22] A. S. M. Fatma, "Histopathological studies on Tilapia zilliiand Solea vulgaris from Lake Qarun, Egypt". World J. Fish and Mar. Sci. 2009, 1(1), 29-39. 
[23] H. Parikh, P. Rangrez, A. Bagchi and B. N. Desai, "Effect of Dimethote on some histoarchitecture of freshwater fish Oreochromis mossambicus (Peters, 1852)". The Bioscan. 2010, 5(1), 55-58.

[24] S. F. Rakhi, AHMM, M. S. Reza and Z. Hossen Hossain, "Alterations in histopathological features and brain acetylcholine esterase activity in stinging catfish Heteropneustes fossilis exposed to polluted river water".Int. Aqua. Resea.2013, 5 (7), 1-18.

[25] A. R. Chourpagar and G. K. Kulkarni, "Heavy metal toxicity to a freshwater crab, Barytelphusa cunicularis (Westwood) from Aurangabad region". Recent Resea.Sci. and Techno. $2011,3(3), 1-5$.

[26] D. S. Castiglioni and M. L. Negreiros- Fransozo, "Breeding season and molt cycle of the fiddler crab Uca rapax (Brachyura, Ocypodidae) in a subtropical estuary, Brazil South Africa". Gulf and Caribbean resea. 2006, 19, 11-20.

[27] A. V. Andhale, P. A. Bhosale and S. P. Zambare, "Histopathological study of nickel induced alterations in the fresh water bivalve, Lammellidens marginalis". J. Exp. Sci. 2011, 2(4), 1-3.

[28] F. I. Shaikh, I. R. Ustad and N. T. Ansari, "Effect of heavy metal on the ovary of fresh water crab, Barytelphusa cunicularis (Westwood)". The Bioscan.2010, 5(2), 335-338.
[29] R. Sarojini, P. R. Machale, A. K. Khan and R. Nagabhushanam, "Effect of cadmium chloride on histology and biochemical contents of the hepatopancreas of the freshwater crab, Barytelphusa guerini". Enviro. Series. 1990, 6, 91-97.

[30] P. S. Kharat, K. B. Shejule and B. C. Ghobale, "Histopathological changes in ovary of fresh water prawn Macrobrachium kistensis exposed to TBTCL". World J. Zoo. 2011, 6(3), 296-300.

[31] A. A. G. Tehrani, Z. Sadeghi Badamchi, N. H. Sanjou Mansoub and A. Azhari, "Effect of Carbamates pesticides on Instar I-II larvae and Adult Artemia urumiana". Annals of Biol. Resea. 2011, 2(3), 515-525.

[32] T. J, Jadhav and J. D. Shaikh, "Histopathological changes in the ovary of freshwater crab, Barytelphusa cunicularis exposed to Endosulphan”. Int. J. Sci. 2012, 1(2), pp. 139-140.

[33] E. Puccia, C. M. Messina, M. V. Cangialosi, P. D'Agati, C. Mansueto, C. PelleritoL. Nagy, V. Mansueto, M. Scopelliti, T. Fiore and L. Pellerito, "Lipid and fatty acid variations in Cionain testinalis ovary after tri-n-butyltin (IV) chloride exposure". Appli. Organometa. Chemis. 2005, 19(1), 23-29. 